\title{
Marine Shell Ear Disks from Protohistoric Caddo Sites on Stoots Creek, Hopkins County, Texas
}

Timothy K. Perttula

Heritage Research Center, Stephen F. Austin State University

Lee Green

Follow this and additional works at: https://scholarworks.sfasu.edu/ita

Part of the American Material Culture Commons, Archaeological Anthropology Commons, Environmental Studies Commons, Other American Studies Commons, Other Arts and Humanities Commons, Other History of Art, Architecture, and Archaeology Commons, and the United States History Commons

Tell us how this article helped you.

This Article is brought to you for free and open access by the Center for Regional Heritage Research at SFA ScholarWorks. It has been accepted for inclusion in Index of Texas Archaeology: Open Access Gray Literature from the Lone Star State by an authorized editor of SFA ScholarWorks. For more information, please contact cdsscholarworks@sfasu.edu. 


\section{Marine Shell Ear Disks from Protohistoric Caddo Sites on Stoots Creek, Hopkins}

County, Texas

\section{Creative Commons License}

\section{(c) (1) \&}

This work is licensed under a Creative Commons Attribution-NonCommercial 4.0 International License 


\section{Marine Shell Ear Disks from Protohistoric Caddo Sites on Stouts Creek, Hopkins County, Texas}

\section{Timothy K. Perttula and Lee Green}

In this article, we discuss three engraved marine shell ear disks from two protohistoric (ca. A.D. 1670-1700) Caddo sites on Stouts Creek in Hopkins County, Texas. These rather unique engraved marine shell disks have only been reported from three other archaeological sites in the entire southern Caddo area. Stouts Creek is a tributary to White Oak Creek. The drainage is situated in the modern Post Oak Savanna, at the far western edge of the distribution of Late Caddo Titus phase sites in Northeast Texas (Perttula 2004: Figure 13.27).

The Stouts Creek marine shell ear disks we report on have been recovered from two different sites in the Stouts Creek valley. One came from a Caddo midden near the Culpepper site (41HP1), a protohistoric Caddo site excavated by The University of Texas in 1931 (Scurlock 1962). This particular marine shell disk has a central perforation and a $13.7 \mathrm{~mm}$ diameter engraved circle on its outer surface (Figure 1).

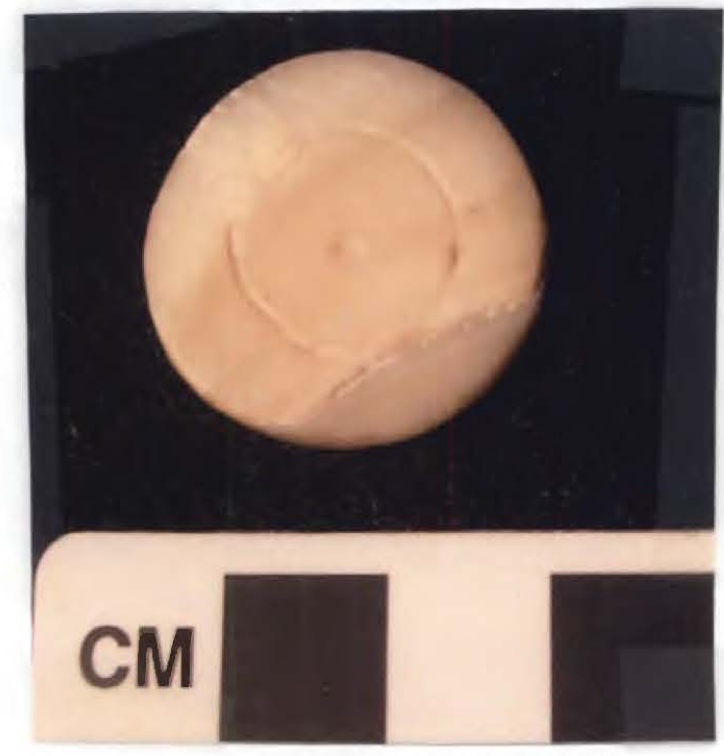

Figure 1. Marine shell disk from a Caddo site near the Culpepper site, Stouts Creek, Hopkins County, Texas.

The other two shell disks (Figures 2 and 3) are from the Anglin Midden site, about $2.5 \mathrm{~km}$ south of the first site on Stouts Creek. These two disks are smaller in size (12.7-22.7 $\mathrm{mm}$ in width) with 8-17.0 engraved circle diameters. 


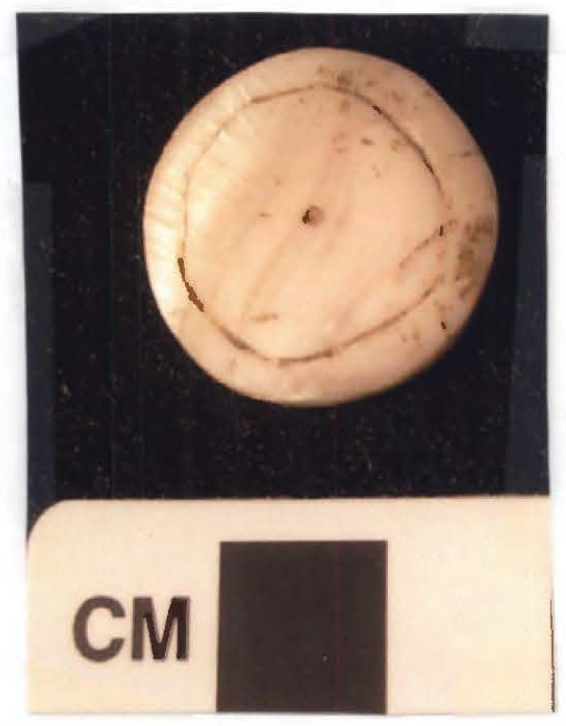

Figure 2. First marine shell disk, Anglin Midden site.

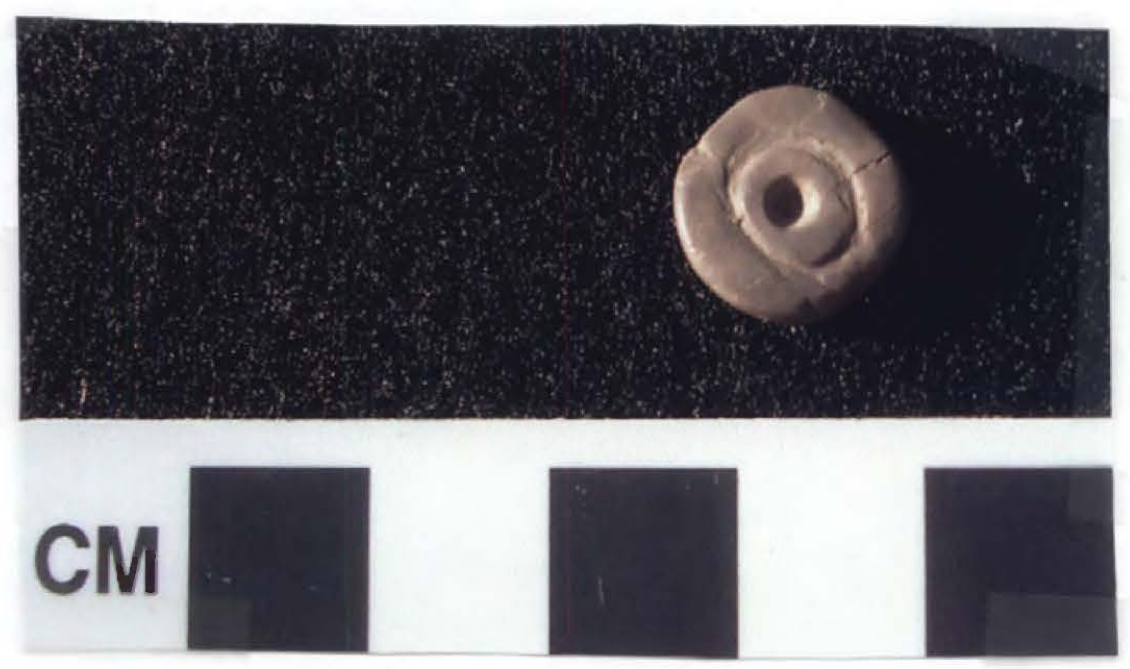

Figure 3. Second marine shell disk from the Anglin Midden site.

Archaeological materials found at these Stouts Creek sites, and other associated sites in the valley, include Talco arrow points and a variety of late Titus phase (i.e., dating after ca. A.D. 1650) ceramic vessels and sherds. These ceramics include the following types: Ripley Engraved, Keno Trailed, Taylor Engraved (Figure 4), Hudson Engraved, and McKinney Plain. 


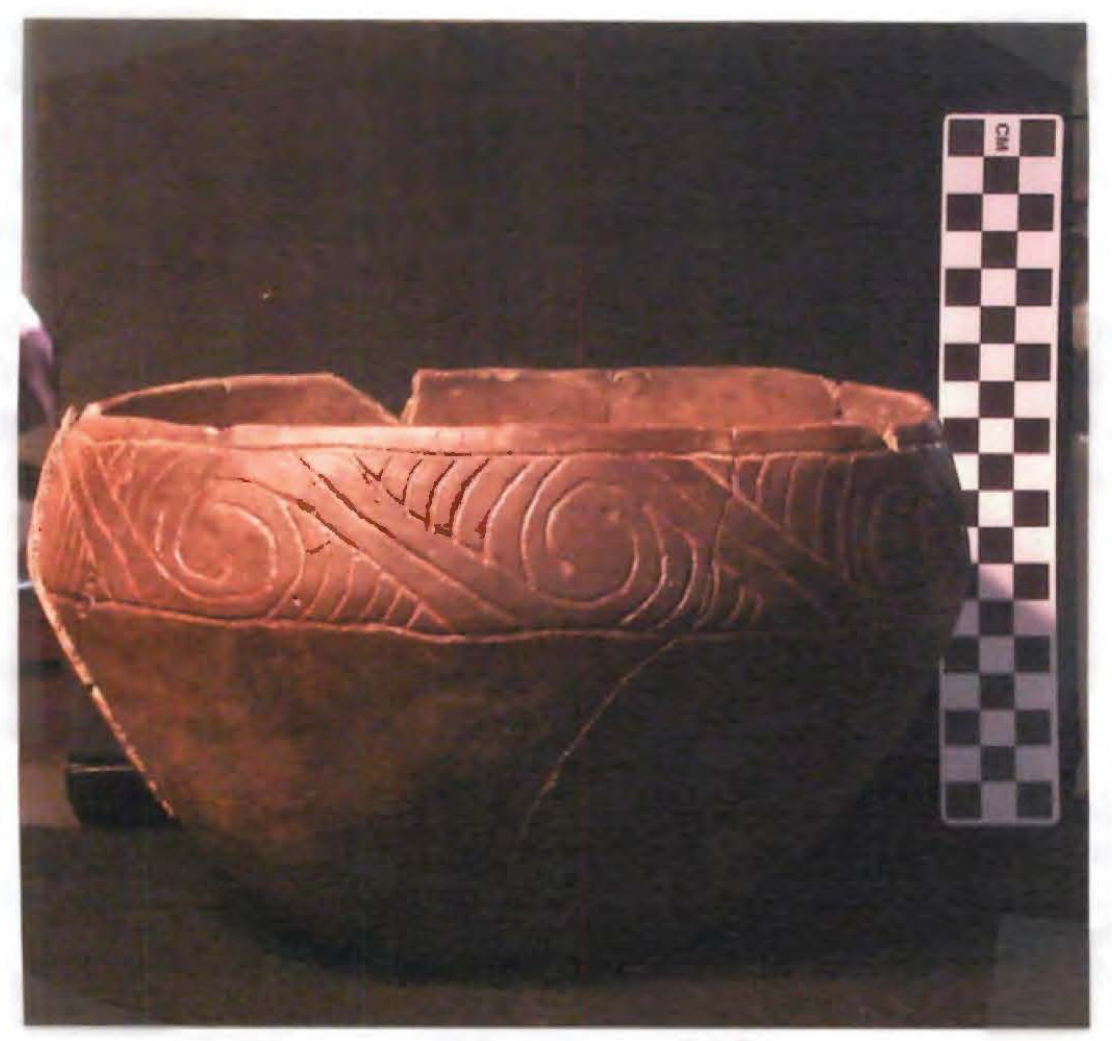

Figure 4. Taylor Engraved vessel from the Tuinier Farm site on Stouts Creek.

At the Culpepper site, other ceramic vessels found in this late Titus phase context include Simms Engraved, Hodges Engraved, Avery Engraved, LaRue Neck Banded, and Nash Neck Banded (Scurlock 1962). Scurlock (1962:296 and Figures 5h-i and 6e) also identified distinctive inverted rim carinated bowls from the Culpepper site cemetery that he suggested were Womack Engraved vessels. However, the engraved motifs on these vessels are not comparable to any Womack Engraved vessels discussed by Harris et al. (1965: Figure 6a-d) or Story et al. (1967: Figures 49-52). Rather, these distinctive Culpepper vessels are actually gracefully decorated Taylor Engraved vessels like those from the Goode Hunt site in Cass County, Texas (Suhm and Jelks 1962: Plate 751), the Cash site in Camp County (Suhm and Jelks 1962: Plate 75o), Clements in Cass County (Perttula et al. 2005: Figures 4.7b and 4.8a), and the Tuinier Farm site on Stouts Creek (see Figure 4).

\section{Regional Comparisons}

In addition to the three engraved shell disks from Stouts Creek valley Caddo sites, engraved marine shell ear disks have also been recovered from protohistoric and early historic burials at three other sites in the southern Caddo area. These are the Clements site in Northeast Texas (Perttula et al. 2005: Figure 4.24a-f; Jackson 1932), in the Chakanina phase occupation at the Cedar Grove site on the Red River in Southwest Arkansas (Kay 1984: 197 and Figure 13-20a-b), and in one Deceiper phase burial at the Hardman site on the Ouachita River in Southwest Arkansas (Early 1993:138-139 and Figure 83a-b). In 
each instance, the Caddo occupations at these three sites can be dated to between ca. A.D. 1650-1700. Consequently, the marine shell disks constitute a clear artifact horizon marker for a late $17^{\text {th }}$ to very early $18^{\text {th }}$ century Caddo occupation wherever they are found. We call them Clements shell disks, because they were first reported from the Clements site (4ICS25) by A. T. Jackson (1932).

The engraved marine shell disks occur in several sizes (Table 1). The largest known are from the Hardman site (57-59.6 $\mathrm{mm}$ in length and $56.4 \mathrm{~mm}$ in width). These also have engraved circles on their outer surface: an inner and outer engraved circle (Early 1993: Figure 83a-b), while those from Stouts Creek, Clements, and Cedar Grove have only a single engraved circle.

Table 1. Engraved Marine Shell Ear Disks.

\begin{tabular}{llllll}
\hline Site & No. & Length $(\mathrm{mm})$ & Width $(\mathrm{mm})$ & Thickness $(\mathrm{mm})$ & $\begin{array}{c}\text { Diam. of Engraved Circle } \\
(\mathrm{mm})\end{array}$ \\
\hline Clements & 2 & $43-51$ & $43-50.8$ & $1.9-3.1$ & $21.4-24.6$ \\
& 4 & $33.5-40$ & $33-38.7$ & $2.3-3.1$ & $15.5-19.5$ \\
Hardman & 2 & $57-59.6$ & 56.4 & $2.0-2.8$ & $\begin{array}{l}\text { inner: } 13.5-20.4 \\
\text { outer: } 53.2\end{array}$ \\
& & & & & $22.5-24.0$ \\
Cedar Grove & 2 & 39.140 .0 & 40.8 & 3.0 & $13.7-17.0$ \\
Stouts Creek & 2 & $22-25$ & $22.7-25.3$ & N/A & 8.0 \\
& 1 & 12.0 & 12.7 & N/A & \\
\hline
\end{tabular}

The Stouts Creek marine shell disks are by far the smallest of the engraved disks, with length and width dimensions ranging from only $12.0-25.3 \mathrm{~mm}$ (see Table 1 and Figure 5). The single engraved circle on the three disks is only $8-17.0 \mathrm{~mm}$ in diameter. The larger shell disks from Clements and Cedar Grove are $33.5-50.8 \mathrm{~mm}$ in length and width, with 15.5-24.6 mm engraved circle diameters. The engraved shell disks reported by Jackson (1932) from Clements are $25-38 \mathrm{~mm}$ in length and width. 


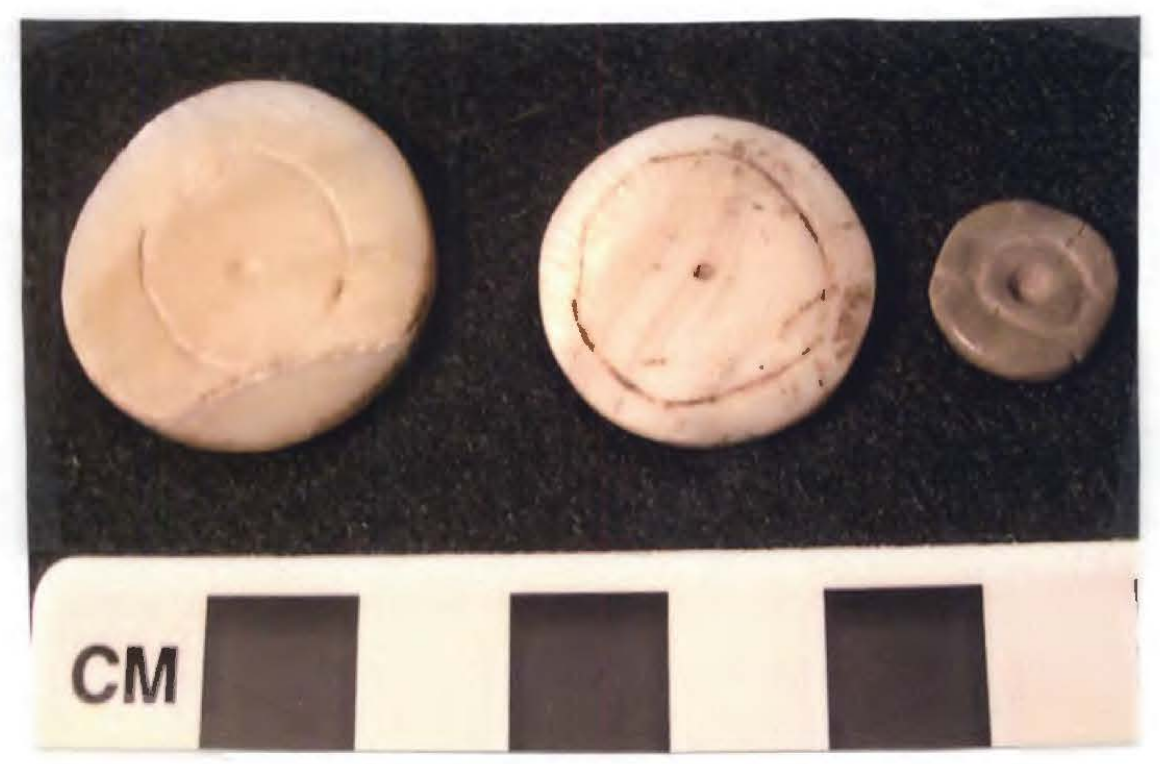

Figure 5. The three Stouts Creek marine shell ear disks.

Similar but plain marine shell disks have been reported from three other protohistoric Caddo sites on the Red River in Northeast Texas and Northwest Louisiana-Bob Williams (Perino 1983:67), Roden (Perino 1981: Figure 4b), and Belcher (Webb 1959:173-174) - as well as the Hardman site (Early 1993: Figure 83c-d). These also have the central perforation.

The plain marine shell disks have generally comparable size ranges as the engraved disks. The smallest ( $16 \mathrm{~mm}$ in diameter) are the disks from Burial Pit 2 at the Belcher site, to the larger (44.5-73 mm diameter) disks from Bob Williams and Hardman, to the very large $(90 \mathrm{~mm})$ shell disks in the northern shaft tomb at the Roden site. The latter shell disks are part of compound cover-covered shell and limestone ear ornaments (Perino 1983:67).

\section{Conclusions}

Clements style marine shell ear disks, both plain and engraved, have been documented as burial goods in eight Caddo archaeological sites in the Ouachita, Red, and Big Cypress stream basins in Northeast Texas, Northwest Louisiana, and Southwest Arkansas. Ceramic vessels found in burials from these sites indicate that the Caddo occupations there took place from ca. A.D. 1650-1700 during the latter part of the Titus, McCurtain, Belcher, Chakanina, and Deceiper phases. The Clements style shell disks are an excellent protohistoric Caddo horizon marker wherever they have been found. 


\section{References Cited}

Early, A. M. (editor)

1993 Caddoan Saltmakers in the Ouachila Valley: The Hardman Site. Research Series No. 43. Arkansas Archeological Survey, Fayetteville.

Harris, R. K., I. M. Harris, J. C. Blaine, and J. Blaine

1965 A Preliminary Archeological and Documentary Study of the Womack Site, Lamar County, Texas. Bulletin of the Texas Archeological Society 36:287-363.

Jackson, A. T.

1932 Exploration of a burial site on Clements Bros. Farm in Cass County, Texas. MS on file, Texas Archeological Research Laboratory, The University of Texas at Austin.

Kay, M.

1984 Late Caddo Subtractive Technology in the Red River Basin. In Cedar Grove: An Interdisciplinary Investigation of a Late Caddo Farmstead in the Red River Valley, edited by N. L. Trubowitz, pp. 174-206. Research Series No. 23. Arkansas Archeological Survey, Fayetteville.

Perino, G.

1981 Archeological Investigations at the Roden Site, McCurtain County, Oklahoma. Publication No. 1, Potsherd Press. Museum of the Red River, Idabel, Oklahoma.

1983 Archaeological Research at the Bob Williams Site (4IRRI6), Red River County, Texas. Potsherd Press. Museum of the Red River, Idabel, Oklahoma.

Perttula, T. K.

2004 The Prehistoric and Caddoan Archeology of the Northeastern Texas Pineywoods. In The Prehistory of Texas, edited by T. K. Perttula, pp. 370-407. Texas A\&M University Press, College Station.

Perttula, T. K., B. Nelson, R. L. Cast, and B. Gonzalez

2005 The W. T. Scott Collection at the American Museum of Natural History. In A Rediscovering of Caddo Herilage: The W. T. Scoll Collection at the American Museum of Natural History and other Caddo Collections from Arkansas and Louisiana, by B. Gonzalez, R. Cast, T. K. Perttula, and B. Nelson, pp. 25-53. Historic Preservation Program, Caddo Nation of Oklahoma, Binger, Oklahoma.

Scurlock, J. D.

1962 The Culpepper Site, A Late Fulton Aspect Site in Northeastern Texas. Bulletin of the Texas Archeological Society 32:285-316. 
Story, D. A., B. Barber, E. Barber, E. Cobb, H. Cobb, R. Coleman, K. Gilmore, R. K. Harris, and N. Hoffrichter

1967 Pottery Vessels. In The Gilbert Site: A Norteno Focus Site in Northeastern Texas, edited by E. B. Jelks. Bulletin of the Texas Archeological Society 37:112-187.

Suhm, D. A. and E. B. Jelks (editors)

1962 Handbook of Texas Archeology: Type Descriptions. Special Publication No. I, Texas Archeological Society and Bulletin No. 4, Texas Memorial Museum, Austin.

Webb, C. H.

1959 The Belcher Mound: A Stratified Caddoan Site in Caddo Parish, Louisiana. Memoirs No. 16. The Society for American Archaeology, Salt Lake City. 